\title{
Assessment of Genetic Divergence for Agro-morphological and Biochemical Traits among Maize (Zea mays L.) Inbred Lines
}

\author{
Ankita Sood ${ }^{\text {** }}$ and S. Lata ${ }^{2}$ \\ ${ }^{1}$ School of Agricultural Sciences, Baddi University of Emerging Sciences \& Technologies, \\ Solan, Himachal Pradesh, India \\ ${ }^{2}$ Department of Crop Improvement, CSK HPKV, Palampur, India \\ *Corresponding author
}

\section{A B S T R A C T}

\begin{tabular}{|c|}
\hline Keywords \\
\hline $\begin{array}{l}\text { Maize, Genetic } \\
\text { variability, Inbred } \\
\text { lines, Cluster } \\
\text { analysis }\end{array}$ \\
\hline Article Info \\
\hline $\begin{array}{l}\text { Accepted: } \\
22 \text { November } 2020 \\
\text { Available Online: } \\
10 \text { December } 2020\end{array}$ \\
\hline
\end{tabular}

\section{Introduction}

Maize (Zea mays L., 2n=20) is one of the nature's most efficient energy-storing cereal. It has originated from Central America (Mexico) from where it spread to different parts of the world due to its wide adaptability and higher productivity potential among the cereals, due to which it is the third most
The present investigation was carried out to assess the nature and magnitude of genetic variability among various traits and to identify potential donor parents among the forty inbreds lines on the basis of genetic divergence for their use in future breeding programs. Data were recorded on grain yield per plot and various morphometric and biochemical traits. Sufficient genetic variability was observed for all the studied traits. Genetic diversity studies using Mahalanobis $\mathrm{D}^{2}$-statistics grouped inbred lines of maize into seven clusters. Maximum inbred lines were placed in cluster I (13 all non-QPM) followed by cluster II (11 all non-QPM) and cluster III (6 all QPM) which indicated that QPM and non-QPM inbred lines were quite different from each other. Highest intra-cluster distance was observed for cluster VI (597.00) suggesting that the inbred lines in this group possess higher degree of genetic variability. Whereas, maximum inter-cluster distance was observed between clusters II and IV (6276.71) indicating that the inbreds belonging to these clusters would produce the best heterosis effect and have more chances of generating the best recombinants. Cluster mean for different traits showed that the cluster IV exhibited maximum divergence for majority of traits viz., cob placement height, 100-seed weight, cob length, cob girth, grains per row, protein content and tryptophan content. Tryptophan content followed by days to 50 per cent pollen shed and grain yield per plot contributed maximum towards genetic divergence. 
scarcity, bio-fuel etc. (Singh et al., 2012). At present the maize improvement should not be viewed merely as a food crop, but improvement due to its increasing industrial demand and the value added products the technology for superior industrial products from maize would be the future priority.

Any breeding programme cannot proceed without having enough variation in the crop to be improved. The first step of any breeding programme is to identify plants that exhibit variation for the trait or traits of interest to the plant breeder that depends on the magnitude of genetic variability. Genetic diversity can be defined as the genetic variation between and within species, which is measured by determining the proportion of polymorphic loci across the genome or by the number of heterozygous individuals in a population. Obviously the diverse parents are expected to have higher frequency of heterotic hybrids besides generating a broad spectrum of variability in segregating generations. Study of genetic diversity is the process by which variation among individuals or groups of individual or populations is analyzed by a specific method or a combination of methods. Statistical procedure such as multivariate analysis based on Mahalanobis $\mathrm{D}^{2}$-statistics serves an important tool in quantifying the degree of genetic divergence among all possible pairs of population at genotypic level in different crops (Rao, 1952, Saxesena et al., 2013). $D^{2}$ - analysis classify the genotypes into different clusters and identifies the genotypically diverse and desirable genotypes.

Differentiation of elite genotypes, particularly inbred lines, based on reliable traits will not only help in preserving identity, but also descriptions based upon traits that can reflect genetic variation are invaluable in analyzing genetic diversity, monitoring and promoting efficient conservation of genetic resources, and effective utilization of germplasm. It helps in studying the nature and magnitude of diversity prevalent in the available germplasm. Thus, assessing the genetic diversity which is an essential first step for identifying appropriate parents for hybridization and generating a broad spectrum of variability in segregating generations for getting desired recombinants. Considering the importance of $\mathrm{D}^{2}$-statistics an investigation was carried out to reveal the kind of genetic divergence exists among the forty maize inbred lines based on agromorphological and biochemical traits.

\section{Materials and Methods}

The experimental material comprised of forty maize inbred lines (fourteen QPM lines and twenty-six normal inbred lines) including four checks viz., CML193, CML180 (QPM checks) and CML429, KI-30 (non-QPM checks). The trial was conducted at Experimental Farm, Department of Crop Improvement, CSKHPKV, Palampur, Himachal Pradesh in alpha randomized block design with three replications (five blocks per replication and eight entries per block with plot size of $3.0 \times 1.2 \mathrm{~m}^{2}$ ) with row to row and plant to plant distance of $60 \mathrm{~cm}$ and $20 \mathrm{~cm}$, respectively (having 2 rows/plot).

The crop was raised by following the recommended package of practices. The observations viz., plant height, cob placement height, cob length, cob girth, kernel rows per ear, grains per row and 100-seed weight were recorded on ten randomly tagged plants in each plot and were averaged. Data on days to $50 \%$ pollen shed, $50 \%$ silking, $75 \%$ maturity and grain yield were recorded on plot basis. The biochemical analysis of inbreds was also done to estimate the protein content for each entry by Micro-Kjeldhal Method (AOAC, 1965) and tryptophan content by method given by Mertz et al., (1975). 


\section{Statistical analysis}

The data was statistically analyzed for variance using the software PROC GLM SAS given by Parsad et al., (2007). For the estimation of genetic divergence among maize inbreds Mahalanobis $\mathrm{D}^{2}$ statistics (1936) was used with the help of Windostat software. The grouping of inbred lines into clusters was done by Toucher's method as described by Rao (1952) with the aid of $\mathrm{D}^{2}$ being treated as the square of the generalized distance.

\section{Results and Discussion}

The basis for any crop improvement is indicated by the genetic variability present in its germplasm material. It helps us to know the main cause of variation and also the sensitivity in expression of various traits to the environment. The perusal of the analysis of variance revealed that the mean sum of squares due to lines were significant for all the characters under study (Table 1). This indicated the presence of sufficient genetic variability among the inbred lines, which provides ample scope for selection for various quantitative characters and quality traits for maize improvement. The results are in congruence with the findings of Dixit et al., (2013), Nayak et al., (2013), Lal and Singh (2014) and Tullu (2014) who also reported significant differences for various morphological and biochemical traits among maize lines.

The $\mathrm{D}^{2}$-statistics provides a powerful conventional tool to quantify the variation in morphometric traits and also to measure the intra and inter group distances to isolate divergent genotypes. Based on the value generated using Tocher's method, forty inbred lines were grouped into seven clusters by treating estimated values as the square of the generalized distance, among them cluster
$\mathrm{V}$ was monogenotypic whereas rest were polygenotypic based on genetic divergence (Table 2). Cluster I formed largest cluster among all with 13 inbred lines (all nonQPM), eleven non-QPM inbred lines formed cluster II. Whereas, cluster III was formed by six QPM inbred lines and three QPM inbred lines formed cluster IV. However, only one non-QPM inbred line KI-30 formed cluster V. Four inbred lines comprising one non-QPM inbred line and three QPM inbred lines viz., CML192, HKI-1348 and CL02450Q formed cluster VI, whereas two QPM inbred lines viz., VQL1 and VQL2 formed cluster VII. The inbred lines were constellated in such way that QPM and non-QPM lines formed separate clusters indicating that they are genetically diverse from each other. Whereas, there is one cluster (VI) having one non-QPM inbred line BAJIM-08-27 (Table 2) along with other QPM inbred lines suggesting that this non-QPM inbred line had close genetic proximity with QPM inbred lines of this cluster and can be easily converted to the QPM inbred line. However, among high yielding non-QPM inbred lines viz., BAJIM08-26 and KI-30 were found to be in different clusters (cluster II and V) showing wide divergence i.e. inter-cluster divergence, which is desirable for future hybridization programme for getting desirable transgressive segregants. These findings are in congruence with Nehvi et al., (2008) and Wang-Li-Feng et al., (2009).

The degree of divergence or diversification among the clusters was specified by the distance between them. Higher the distance between the two groups higher the genetic divergence and vice versa. As it stated earlier, genotypes with higher genetic divergence produces best heterosis effect and have more chances of generating the best recombinants. Highest intra-cluster distance was observed for cluster VI (597.00) followed by cluster VII (345.99) and cluster III (329.14). Cluster 
VI showed highest intra-cluster distance with only four inbred lines indicating that the inbred lines within the same cluster were quite diverse compare to the inbred lines clustered in other groups and can be recommended for the utilization in further breeding program. Though, Cluster I contains highest number of inbred lines but recorded the lowest intra cluster distance (147.84). It is believed that inbred lines belonging to this cluster are more or less similar to each other due to considerably lower intra cluster distance. Cluster II containing eleven inbred lines still recorded intra cluster distance (278.42) higher than cluster I indicating inbred lines under this group possess some degree of genetic variability compare to genotypes belong to cluster I.

Table.1 Analysis of variance for agro-morphological and biochemical traits in maize inbred lines

\begin{tabular}{|c|c|c|c|c|}
\hline Source of variation & plication & $\begin{array}{l}\text { Blocks } \\
\text { within } \\
\text { replication }\end{array}$ & Lines & Error \\
\hline Days to $50 \%$ pollen shed & $3.675^{*}$ & 0.691 & $138.292 *$ & 0.642 \\
\hline Days to $50 \%$ silking & $4.433^{*}$ & 0.375 & $141.693 *$ & 0.696 \\
\hline Days to $75 \%$ maturity & $6.808^{*}$ & 0.486 & $143.056^{*}$ & 0.826 \\
\hline Plant height (cm) & $237.493 *$ & 63.059 & $1829.438^{*}$ & 52.066 \\
\hline Cob placement height $(\mathrm{cm})$ & $102.951 *$ & 16.829 & $624.127 *$ & 22.821 \\
\hline Grain yield/plot (g) & 3198.090 & 4552.500 & $329824.130 *$ & 4154.530 \\
\hline 100-seed weight $(\mathrm{g})$ & 2.524 & 2.851 & $50.661 *$ & 2.355 \\
\hline Cob length $(\mathrm{cm})$ & $12.013 *$ & 1.053 & $8.773 *$ & 1.114 \\
\hline Cob girth (cm) & $7.343^{*}$ & 0.456 & $7.494 *$ & 0.987 \\
\hline Kernel rows/ear & $7.300^{*}$ & 0.417 & $5.708 *$ & 1.157 \\
\hline Grains per row & $45.108 *$ & 6.339 & $73.582 *$ & 9.319 \\
\hline Protein content $(\%)$ & 0.049 & 0.071 & $1.632 *$ & 0.040 \\
\hline Tryptophan content (\%) & 0.0003 & 0.0005 & $0.1030 *$ & 0.0004 \\
\hline
\end{tabular}

*Significant at $\mathrm{P} \leq 0.05$

Table.2 Distribution of maize inbred lines into different clusters based on Mahalanobis $\mathrm{D}^{2}$ values

\begin{tabular}{|c|c|c|}
\hline Clusters & Number of inbred lines & Inbred lines \\
\hline Cluster I & 13 & $\begin{array}{l}\text { CM126, KI-18, CM128, CM129, CM212, KI-29, } \\
\text { CM145, CML470, BAJIM-11-3, CM127, KI-16, } \\
\text { BAJIM-11-4, CM152 }\end{array}$ \\
\hline Cluster II & 11 & $\begin{array}{l}\text { CML451, CML481, CML472, CML496, CL02450, } \\
\text { CML474, CML473, CML429, BAJIM-11-1, } \\
\text { BAJIM-08-26, BAJIM-11-2 }\end{array}$ \\
\hline Cluster III & 6 & $\begin{array}{l}\text { CML170, CML451Q, CML193, CML163, CML171, } \\
\text { CML169 }\end{array}$ \\
\hline Cluster IV & 3 & CML162, CML180, CML189 \\
\hline Cluster V & 1 & KI-30 \\
\hline Cluster VI & 4 & CML192, HKI-1348, CL02450Q, BAJIIM-08-27 \\
\hline Cluster VII & 2 & VQL1, VQL2 \\
\hline
\end{tabular}


Table.3 Average intra and inter-cluster values of $\mathrm{D}^{2}$ and $\sqrt{\mathrm{D}^{2}}$ among seven clusters

\begin{tabular}{|c|c|c|c|c|c|c|c|}
\hline Clusters & $\underset{\text { I }}{\text { Cluster }}$ & Cluster II & $\begin{array}{c}\text { Cluster } \\
\text { III }\end{array}$ & Cluster IV & $\begin{array}{c}\text { Cluster } \\
\text { V }\end{array}$ & $\begin{array}{c}\text { Cluster } \\
\text { VI }\end{array}$ & $\begin{array}{c}\text { Cluster } \\
\text { VII }\end{array}$ \\
\hline Cluster I & $\begin{array}{l}147.84 \\
(12.16)\end{array}$ & $\begin{array}{l}742.27 \\
(27.24)\end{array}$ & $\begin{array}{c}3524.53 \\
(59.37)\end{array}$ & $\begin{array}{c}6223.28 \\
(78.89)\end{array}$ & $\begin{array}{l}411.33 \\
(20.28)\end{array}$ & $\begin{array}{r}2004.45 \\
(44.77)\end{array}$ & $\begin{array}{r}2733.89 \\
(52.29)\end{array}$ \\
\hline Cluster II & & $\begin{array}{l}278.42 \\
(16.68)\end{array}$ & $\begin{array}{r}3246.70 \\
(56.98)\end{array}$ & $\begin{array}{c}6276.71 \\
(79.22)\end{array}$ & $\begin{array}{l}645.25 \\
(25.40)\end{array}$ & $\begin{array}{c}1517.16 \\
(38.95)\end{array}$ & $\begin{array}{r}3518.11 \\
(59.31)\end{array}$ \\
\hline $\begin{array}{c}\text { Cluster } \\
\text { III }\end{array}$ & & & $\begin{array}{l}329.14 \\
(18.14)\end{array}$ & $\begin{array}{l}864.70 \\
(29.40)\end{array}$ & $\begin{array}{c}3042.68 \\
(55.16)\end{array}$ & $\begin{array}{l}897.71 \\
(29.96)\end{array}$ & $\begin{array}{l}787.91 \\
(28.07)\end{array}$ \\
\hline $\begin{array}{c}\text { Cluster } \\
\text { IV }\end{array}$ & & & & $\begin{array}{l}192.68 \\
(13.88)\end{array}$ & $\begin{array}{c}5383.10 \\
(73.37)\end{array}$ & $\begin{array}{c}2336.63 \\
(48.34)\end{array}$ & $\begin{array}{c}1159.96 \\
(34.06)\end{array}$ \\
\hline Cluster V & & & & & $\begin{array}{c}0.00 \\
(0.00)\end{array}$ & $\begin{array}{c}1437.45 \\
(37.91)\end{array}$ & $\begin{array}{c}2562.48 \\
(50.62)\end{array}$ \\
\hline $\begin{array}{c}\text { Cluster } \\
\text { VI }\end{array}$ & & & & & & $\begin{array}{l}\mathbf{5 9 7 . 0 0} \\
(\mathbf{2 4 . 4 3 )}\end{array}$ & $\begin{array}{c}1368.83 \\
(36.99)\end{array}$ \\
\hline $\begin{array}{c}\text { Cluster } \\
\text { VII }\end{array}$ & & & & & & & $\begin{array}{l}345.99 \\
(18.60)\end{array}$ \\
\hline
\end{tabular}

Bold diagonal values represent intra-cluster distances; whereas data in parenthesis are $\sqrt{D^{2}}$ values

Table.4 Cluster means for different traits of maize inbred lines

\begin{tabular}{|c|c|c|c|c|c|c|c|c|c|c|}
\hline Traits & Cluster I & $\begin{array}{c}\text { Cluster } \\
\text { II }\end{array}$ & $\begin{array}{c}\text { Cluster } \\
\text { III }\end{array}$ & $\begin{array}{c}\text { Cluster } \\
\text { IV }\end{array}$ & $\begin{array}{c}\text { Cluster } \\
\text { V }\end{array}$ & $\begin{array}{c}\text { Cluster } \\
\text { VI }\end{array}$ & $\begin{array}{l}\text { Cluster } \\
\text { VII }\end{array}$ & Mean & Minimum & Maximum \\
\hline $\begin{array}{l}\text { Days to } 50 \% \\
\text { pollen shed }\end{array}$ & 57.26 & 70.15 & $70.78 * *$ & 64.22 & 57.00 & 69.50 & $56.83^{*}$ & 63.68 & 56.83 & 70.78 \\
\hline $\begin{array}{l}\text { Days to } 50 \% \\
\text { silking }\end{array}$ & 59.08 & 72.06 & $72.89 * *$ & 66.33 & 59.00 & 71.75 & $58.17 *$ & 65.61 & 58.17 & 72.89 \\
\hline $\begin{array}{l}\text { Days to } 75 \% \\
\text { maturity }\end{array}$ & 94.92 & 108.09 & $108.83 * *$ & 102.22 & 95.00 & 107.58 & $94.33^{*}$ & 101.57 & 94.33 & 108.83 \\
\hline $\begin{array}{l}\text { Plant height } \\
\text { (cm) }\end{array}$ & 132.19 & 143.09 & 143.30 & 175.89 & $\begin{array}{c}177.40 \\
* *\end{array}$ & 142.03 & $131.93 *$ & 149.40 & 131.93 & 177.40 \\
\hline $\begin{array}{l}\text { Cob placement } \\
\text { height }(\mathrm{cm})\end{array}$ & 55.94 & 66.83 & 61.87 & $89.62 * *$ & 80.80 & 69.87 & $54.67 *$ & 68.51 & 54.67 & 89.62 \\
\hline $\begin{array}{l}\text { Grain yield/plot } \\
\text { (g) }\end{array}$ & $715.59 *$ & 976.02 & 812.92 & 1017.60 & $\begin{array}{c}1549.8 \\
8 * *\end{array}$ & 1308.29 & 741.24 & 1017.36 & 715.59 & 1549.88 \\
\hline $\begin{array}{l}\text { 100-seed weight } \\
\text { (g) }\end{array}$ & 20.54 & 23.79 & 20.22 & $26.34 * *$ & 25.99 & 24.51 & $19.26 *$ & 22.95 & 19.26 & 26.34 \\
\hline Cob length $(\mathbf{c m})$ & 10.93 & 10.89 & 11.92 & $14.41 * *$ & 11.89 & 11.83 & $10.69 *$ & 11.79 & 10.69 & 14.41 \\
\hline Cob girth $(\mathrm{cm})$ & $11.20^{*}$ & 11.88 & 11.21 & $13.76 * *$ & 13.50 & 13.19 & 11.59 & 12.33 & 11.20 & 13.76 \\
\hline Kernel rows/ear & $11.95^{*}$ & 12.36 & 12.56 & 13.78 & 13.33 & 13.17 & $15.00 * *$ & 13.16 & 12.36 & 15.00 \\
\hline Grains/row & 22.21 & 21.91 & $19.78^{*}$ & $30.11 * *$ & 26.67 & 23.50 & 21.67 & 23.69 & 19.78 & 30.11 \\
\hline $\begin{array}{l}\text { Protein content } \\
\text { (\%) }\end{array}$ & 8.67 & $8.43^{*}$ & 9.58 & $9.88 * *$ & 9.73 & 8.86 & 9.25 & 9.20 & 8.43 & 9.88 \\
\hline $\begin{array}{l}\text { Tryptophan } \\
\text { content }(\%)\end{array}$ & 0.45 & 0.47 & 0.84 & $1.00 * *$ & $0.40 *$ & 0.72 & 0.84 & 0.67 & 0.40 & 1.00 \\
\hline
\end{tabular}

$*$ and $* *$ : minimum and maximum values, respectively 
Cluster $\mathrm{V}$ fail to generate intra cluster value due to the presence of only one inbred line. It is stated that cluster showing higher intra cluster distance indicates the presence of sizeable genetic variability in the inbred lines. It is thus, advisable that breeder can chose the genotypes from cluster VI due presence of sizeable degree genetic variability over the other clusters. The chances of developing good segregants by crossing the genotypes of the cluster having low value for intra-cluster distance are possible by attempting crosses between the genotypes of clusters separated by large inter-cluster distances.

Highest inter-cluster distance was observed between clusters II and IV (6276.71) followed by clusters I and IV (6223.28) and clusters IV and V (5383.10). Thus, inbreds belonging to cluster II and cluster IV can be recommended for the utilization in hybridization program. Cluster distance between the cluster I and cluster V (411.33) was lowest among all the groups due to close relationship among inbreds of these groups. Inter and intra cluster distances of seven clusters are given in the Table 3. Present findings are in consonance with those previously reported by Singh et al., (2005), Kumar et al., (2011), Alam et al., (2013) and Reddy et al., (2013) thus suggesting that the genotypes belonging to the clusters separated by high statistical distance could be used in hybridization programme for obtaining a wide spectrum of variation among the segregants.

The cluster mean values for different traits of maize inbred lines falling under different clusters are presented in Table 4 . The cluster mean values generated by varying number of inbreds in each cluster, however cannot be used for statistical comparison, but could be utilized to get a comparative idea of diversity and divergence among the clusters they are compared. Based on the range of means for each character, it became possible to know the characters influencing the divergence. The average cluster mean values for different traits showed that the inbred lines included in cluster I showed minimum cluster mean values for grain yield per plot, cob girth and kernel rows per ear. Cluster II showed minimum value for protein content. Cluster III showed maximum values for days to 50 per cent pollen shed, days to 50 per cent silking and days to 75 per cent maturity and minimum for grains per row. For cob placement height, 100-seed weight, cob length, cob girth, grains per row, protein content and tryptophan content cluster IV showed maximum values. Cluster V showed maximum values for plant height and grain yield per plot and minimum value for tryptophan content. Cluster VII showed maximum value for kernel rows per ear and minimum values for days to 50 per cent pollen shed, days to 50 per cent silking, days to 75 per cent maturity, plant height, cob placement height, 100-seed weight and cob length.

Among seven clusters, cluster IV showed the maximum cluster mean values for maximum number of traits, suggesting that these traits were superior over other traits and inbred lines falling in cluster IV would be selected directly on the basis of these traits and could be used in hybridization programs. Similar results were obtained by Singh et al., (2005) who reported that cluster IV had the highest values of cluster means for 50 per cent tasseling, silking, plant height, cob height, cob length, number of grains per row and 100-grain weight. Based on cluster means wide range of variation for grain yield and its components in maize was also reported by Singh et al., (2007).

In conclusion the overall study revealed the predominant and significant variation for all the studied traits among the forty inbred lines indicating the presence of considerable 
amount of genetic variability in the present population. Divergence study, suggested that inbred lines belonging to clusters II and IV may be used as suitable parents in the future hybridization programme. The derived information of this research on maize inbred lines would be very useful to select potentially breeding lines for future maize improvement programme.

\section{Acknowledgment}

The authors feel privileged to thank Department of Crop Improvement, CSKHPKV, Palampur, Himachal Pradesh, India for their technical and financial assistance.

\section{References}

Alam, M.A., Khan, A.A., Islam, M.R., Ahmed, K.U. and Khaldun, A.B.M. 2013. Studies on genetic divergence in maize (Zea mays L.) inbreds. Bang. J. Agric. Res., 38: 71-76.

AOAC. 1965. Official methods of analysis of the association of official agricultural chemists, Washington DC, pp. 744-745.

Dixit, V.A., Sharma, D. and Marker, S. 2013. Studies on heritability and genetic advance estimates in maize genotypes. Biosci. Disc., 4: 165-168.

Kumar, V., Singh, P.K. and Gupta, A. 2011. Studies of genetic diversity in quality protein maize (Zea mays L.) inbreds. Curr. Adv. Agric. Sci., 3: 96-99.

Lal, M. and Singh, D. 2014. Studies of variability using morphological and quality traits in quality protein maize (Zea mays L.). Electron. J. Plant Breed., 5: 526-530.

Mahalanobis, P.C. 1936. On the generalized distance in statistics. Proc. Nat. Acad. Sci., 2: 49-55.

Mertz, E.T., Bunathan, J.R. and Misra, P.S. 1975. In Protein Quality, Agric
Experiment Stn. Bull No. 70 Purdue University, USA: 11.

Nayak, V.H., Singh, R. and Potla, K.R. 2013. Genetic variability analysis of yield and yield related traits in inbred lines of maize (Zea mays L.). Envi. and Eco., 31: 1669-1671.

Nehvi, F.A., Makhdoomi, M.I., Vaseem Yousuf Bahar, F.A. and Naseer, S. 2008. Genetic divergence among local maize (Zea mays L.) cultivars of Kashmir Valley. J. Eco-friendly Agric., 3(2): 130-133.

Parsad, R., Gupta, V.K., Batra, P.K., Satpati, S.K. and Biswas, P. 2007. $\alpha$-Designs. IASRI, New Delhi.

Rao, C.R. 1952. Advanced Statistical Methods in Biometrical Research. John Wiley and Sons, New York. pp 390.

Reddy, V.R., Jabeen, F. and Sudarshan, M.R. 2013. Genetic divergence in maize (Zea mays L.). Prog. Agric., 13: 14-18.

Saxesena, R. R., Lal, G. M., Yadav, P. S. and Vishwakarma, M. K. (2013). Diversity analysis and identification of promising lines for hybridization in field pea (Pisum sativum L.). Bioscan., 8 (4): 1337-1340.

Singh, N., Rajendran, R.A., Shekhar, M., Jat, S.L., Kumar R. and Kumar, R.S. 2012. Rabi Maize Opportunities Challenges, Directorate of Maize Research, Pusa Campus, New Delhi -110 012, Technical Bull., 9: 32.

Singh, P., Dwivedi, S.D., Kumar, V.K. and Sangwan, Y.O. 2005. Genetic divergence studies in maize (Zea mays L.). Ann. Agric. Bio. Res., 10(1): 43-46.

Singh, S.B., Gupta, B.B. and Singh, S.P. 2007. Genetic divergence in exotic inbreds of maize (Zea mays L.). Prog. Agric., 7: 1-4.

Tullu, B.N. 2014. Correlation and path coefficients analysis studies among yield and yield related traits of quality 
protein maize (QPM) inbred lines. Int. J. Plant Breed. and Crop Sci., 1: 6-17.

Wang, Li.Feng., Li, Hui. Yong., Tang, Bao.Jun., Cheng, Ze. Qiang., Wang, Zhen.Hua. and Tie, Shuang. Gui. 2009. Genetic diversity analysis of Henan maize landrace by phenotype and simple sequence repeat (SSR) markers. Scientia Agricultura Sinica, 42(4): 1136-1144.

\section{How to cite this article:}

Ankita Sood and Lata, S. 2020. Assessment of Genetic Divergence for Agro-morphological and Biochemical Traits among Maize (Zea mays L.) Inbred Lines. Int.J.Curr.Microbiol.App.Sci. 9(12): 2995-3002. doi: https://doi.org/10.20546/ijcmas.2020.912.354 